УДК 739.2; 7.032; 7.033.2;

ББК 85.125

DOI:10.18688/aa155-2-19

Jenny Albani

\title{
Antiquity Reused. Antique Engraved Gems on Byzantine Rings ${ }^{1}$
}

It is nowadays generally accepted that the Byzantines were familiar with the art of antiquity. This is mainly visible in the artistic activity of the so-called Byzantine "renaissances". The display of ancient statues in public places of Byzantine cities, probably over one hundred in Constantinople during the middle Byzantine period [30, p. 58], and the reuse of spolia in buildings are well documented $[6 ; 7 ; 27 ; 36 ; 8 ; 40]$. Moreover, it is believed that antique engraved gems, namely intaglios and cameos manufactured prior to the $4^{\text {th }}$ century $\mathrm{AD}$, were collected in Byzantium [31, pp. 58-62]. The majority of these precious stones are now in the West where they arrived either as diplomatic gifts and purchases or as spoils of the Fourth Crusade [23, p. 113; 43, p. 2]. They were reused there by rulers, members of the aristocracy and high-ranking prelates to embellish precious liturgical objects as well as insignia and jewels [31, pp. 58-59; 52, pp. 249-270; 46, p. 1 n. 2]. It is interesting to note that no sacred objects of Byzantine origin, decorated with ancient engraved gems, have come down to us. It has, however, been argued that the Byzantines too, by engraving new inscriptions on antique cameos, altered their original meaning and attached them to religious objects like reliquaries and book covers [31, pp. 58-62; 32, p. 81]. On the other hand, extant Byzantine jewels, mostly rings, set with antique engraved gems, although significantly fewer than the Western ones, prove that the Byzantines also followed this practice.

How did the Byzantines "reuse antiquity" in relation to their rings, these precious objects of prestige or personal adornment? Which of the devices found on antique gems were selected to decorate Byzantine rings of antiquarian taste? Did these retain their original meaning or were they affected by the Christian faith? Can we speculate on the identity of the rings' owners? These are the questions which this paper will try to address even if it may not be always possible to give any definite answer.

Five rings of probable Byzantine manufacture and a post-iconoclastic date can shed light on these topics. The first (Ill. 33), a gilt bronze ring, is an excavation find from a middle Byzantine tomb at the settlement Hagios Pavlos in Gavalochori, Western Crete, and is today on show in

1 I would like to thank Mr. Michael Andrianakis, Honorary Director of the $28^{\text {th }}$ Ephorate of Byzantine Antiquities, Chania, Crete, and Dr. George Kavvadias, Head of the Department of Vases, Minor Arts and Metalworks Collections at the National Archaeological Museum, Athens, for granting me permission to publish the ring in the Byzantine and Postbyzantine Collection of Chania, Crete, and the ring inv. no. $\Sigma \tau 472$ in the National Archaeological Museum, Athens, respectively. My thanks are also due to Ms. Ruth Bowler, Photo and Digital Imaging Coordinator at the Walters Art Museum, Baltimore, for kindly providing me with a digital photograph of the ring inv. no. 57. 1580 in the Walters Art Museum. Moreover, I am particularly indebted to my colleagues Dr. Ioanna Christoforaki, Athens Academy, Prof. Demetrios Plantzos, Athens University, $\mathrm{PhD}$ cand. Eleni Charchare, Athens University, and Dr. Demetrios Doumas for their useful remarks. 
the Byzantine and Post-Byzantine Collection of Chania on Crete [2, pp. 130-131, figs. 14-15, pl. 8]. Its plain hoop is decorated with two bosses, to the right and left of the bezel with an oval intaglio of cornelian, the favorite stone of the Romans [38, p. 6]. Since the gem has a flat face and a classicizing style it may be dated to the late $1^{\text {st }}$ or $2^{\text {nd }}$ century $\mathrm{AD}[44, \mathrm{p}$. 77]. It depicts two male figures in conversation: to the left a young satyr with a horse tail stands in front of a bearded one, to the right, who sits on a rock and holds a round shield. Similar iconography, which probably derives from scenes of Hephaistos' workshop, is seen in three Roman gems ${ }^{2}$. Satyrs, Dionysos' attendants, were a popular motif of Roman gems of the late Republican and the Augustan era. In antiquity their representations on helmets, vases, gems and other artefacts had an apotropaic character since these creatures were considered as personifications of evil [22, p. 316]. Even the word "satyr" had the meaning of a salacious and lascivious man [25, p. 41] not only in antiquity but also in Byzantium. The term has, for instance, a negative meaning in the Chronographia of Theophanes Continuatus (4.38) who presents the companions of the emperor Michael III as satyrs ${ }^{3}$.

The major question is whether the Byzantines could identify mythological subjects. There is sufficient evidence that the upper classes in middle and late Byzantine times were acquainted with Graeco-Roman religion and mythology [51, pp. 45-46; 49; 50]. The $11^{\text {th }}$-century historian and courtier Michael Psellos, for instance, tells us in his Chronographia (VI, 60) that Maria Skleraina, Constantine IX Monomachos' mistress, while living in the imperial palace as sebaste, asked him again and again about Greek myths. Moreover, she herself here and there used to add a point that she had learnt from experts on these subjects ${ }^{4}$. The supposition that learned Byzantines could identify the satyrs of the Gavalochori ring stone is further reinforced by the fact that these mythological creatures appeared not only in late antique but also in posticonoclastic art. For example, in a miniature of the $11^{\text {th }}$-century illuminated manuscript of the Pseudo-Oppian Cynegetica, which once belonged to Cardinal Bessarion and is now in the Biblioteca Nazionale Marciana, Venice (cod. gr. 479), three satyrs are depicted together with a centaur [50, p. 113, fig. 123].

Our second ring (Ill. 34) [4, p. 332 no. 235] is part of the so-called "Thessalonike hoard", namely a hoard that is said to have been found in the region of Thessalonike and belongs to the Stathatos Collection at the National Archaeological Museum of Athens (inv. no. $\Sigma \tau$ 472) [5; 4, pp. 48-57]. This hoard is datable to around 1200 since it contained coins of Isaac Angelos (1186-1195) and Alexios III Angelos Komnenos (1105-1204). Apart from the coins it contained 14 rings, a pair of earrings and a pair of bracelets. The ring in question is gold, set with an antique cornelian intaglio depicting a female mask in profile, with grotesque features

\footnotetext{
2 On a cornelian (mid-first century BC) in the J. Paul Getty Museum, Los Angeles [44, no. 183, p. 82], a sardonyx (late Republican period) from the once Currie Collection [17, p. 149 no. 34. 14, pl. XXX/34] and a cornelian (second-first century BC) in the Herzog-Anton-Ulrich-Museum, Braunschweig [41, p. 13, no. 12; pl. 3/12].

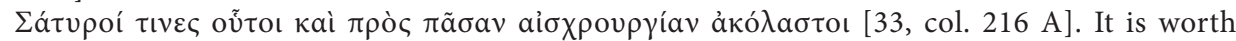
mentioning that a sinner with the fragmentary inscription $O[C A] T Y P[O] C$ is depicted among the damned in Hell in a wall painting (around 1400) of the Church of St. John in Axos, in the region of Mylopotamos, Crete [1].

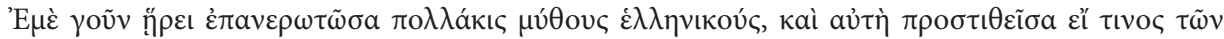

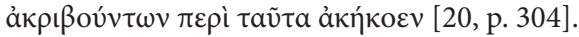


and an open mouth. Such masks were presumably used by actors. In view of its style and the stone's convex shape the intaglio can be dated to the $2^{\text {nd }}$ or $1^{\text {st }}$ century $B C^{5}$.

Human masks were very popular in late Byzantine art, namely in monumental painting, miniatures and icons. They usually appeared in representations of buildings and furniture as well as of the armour of military saints and Archangel Michael [34, pp. 308-313, 322-328]. They may, therefore, be interpreted in terms of their apotropaic qualities. On the other hand, the mask motif, usually depicted on wall paintings of aristocratic patronage, as for example the frescoes of the funerary chapel in the Chora monastery, Constantinople, and the Mystras churches, indicate the antiquarian taste of the Byzantine social elite. Moreover, since masks of an anti-classical appearance were very popular in the $\mathrm{West}^{6}$, they also illustrate one aspect of Western influence on Byzantine art [34, pp. 328-335].

Three late Byzantine gold rings with Greek inscriptions outlined with nielo, which is today lost in some spots, are set with octagonal nicolo intaglios ${ }^{7}$. Probably these engraved gems, dated to the $2^{\text {nd }}-3^{\text {rd }}$ century $\mathrm{AD}$, were originally oval in shape, as the majority of antique Roman engraved gems, and had been cut down to fit the shape of the ring bezel $[47$, p. 48$]$. Owing to their fine workmanship the three rings have been attributed to a $14^{\text {th }}$ century workshop related to the imperial court in Constantinople and influenced by Western models [47, p. 48].

The third ring (Ill. 35), today in the Walters Art Museum, Baltimore, inv. no. 57.1580 [47, p. 36, cat. 20, with literature, pl. 7], has a broad, carinated hoop which is elaborately decorated with carved scrollwork and two shields with heraldic lions on the shoulders. On the bezel's gem Pan is represented bearded, goat-footed, holding his characteristic pipes. The inscription carved in relief around the edge of the bezel reads KE COTHP MOY THNA $\Phi$, a quotation from Psalm 27 (Lord is my Light and my Savior, whom shall I fear?). Biblical verses were rarely engraved on rings, except for the trisagion and Psalm 90 (the latter was considered to have protective powers). According to the $6^{\text {th }}$-century hymnographer Romanos the Melode, chanting of psalms and hymns could scathe demons, who are mankind's eternal enemies ${ }^{8}$.

In Greek religion and mythology the goat-horned and legged god Pan was related to pastoral life, rural music (since he invented the pipes), divining art and sensual pleasure. Arkadia in the Peloponnese was the principal seat of his worship, but his cult had also spread in Attica since the $5^{\text {th }}$ century BC because he was believed to have created panic among the Persian army at the Marathon battle [22, pp. 240-243; 21, p. 193; 42.]. Byzantine writers characterized composite creatures from pagan mythology as unrealistic and

\footnotetext{
5 For parallels [44, p. 92, no. 216. 17, p. 132 nos. 57, 58. 14, pl. XXVI, nos. 57, 58].

6 E.g.: two masks in relief in the cathedrals of Reims and Bamberg and another in a fountain from the abbey of St. Denis, today in the court of the École des Beaux-Arts, Paris [19, figs. 116, 118, 119].

$7 \quad$ A nicolo intaglio is an onyx gem engraved in such a way that the image displays a translucent bluish-grey colour. Under this thin top layer is a thicker layer of dark material.

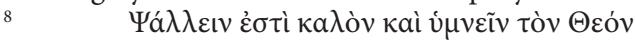

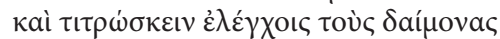

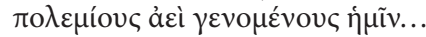

(It is good to sing psalms and hymns to God And to scourge with reproaches the demons Who are our eternal enemies... [24, p. 275 n. 3].
} 
absurd. Thus, negative comments on Pan are not rare in Byzantine literature [28, pp. 190$191 ; 13$, p. 8]. A typical example is a - probably $-10^{\text {th }}$-century encomium of a stylite saint Alypios, by a certain Antony, monk and priest of St. Sophia's chapels [18, pp. 5, 168-169], which refers to him as "the most ludicrously laughable of the lot - a mixture of different natures and faculties"9. However, despite the negative connotations, which mythological composite creatures, such as tritons, centaurs, satyrs, sphinxes, bull-lions and snake-legged giants, had in Byzantine religious texts, they appeared frequently in Byzantine art, both religious and secular. The well-educated social elite, residing mainly in Constantinople, was probably attracted by pagan iconographic inventions as implied by numerous ivory boxes, tableware, sculptures and illuminated manuscripts, decorated with composite creatures [28, pp. 192 ff. 11, pp. 44-46; 13, pp. 11-28]. The reused engraved gem with the image of Pan in the Baltimore ring is related to this profane antiquarian aesthetic. Probably aware, however, of the demonic properties ascribed to Pan by Christian writers, the ring's owner explained his iconographic choice by the inscription around the pagan image: since he has gained holy protection, why should he be afraid of a curious creature? The ring had, therefore, a talismanic character. Moreover, the lion is a symbol of the victorious Christ, according to the Revelation (5:5 $)^{10}$. As symbols of strength, bravery and authority heraldic lions and lion masks decorate the armour and shield of soldier saints and Archangel Michael on late Byzantine icons and wall paintings ${ }^{11}$. From the Roman period onwards, some images engraved on rings were chosen because of a special relevance to their owners [38, p. 4]. We may, therefore, suggest that this precious ring could belong to a high-ranking military officer. On the other hand, some Venetian influence in the choice of the lion motif cannot be excluded.

The fourth ring of this late Byzantine group belongs to the British Museum, London (inv. no. AF 563 [47, p. 36 no. 24, with literature, pl. 7]. Its intaglio depicts Bonus Eventus represented as a full-length male figure in profile, with one leg bent. He is nude, wearing only a chlamys, and holds a dish of fruits and a branch. His iconographic type (the so-called second type of Bonus Eventus) was very popular in the Imperial period ${ }^{12}$. Around the edge of the bezel runs a carved inscription beginning with a cross: KIPHOC $\Phi \Omega T I C M O C$ MOY KE COTHP MOY TINA $\Phi$ (Lord is my Light and my Savior, whom shall I fear? Psalm 27:1). The hoop is decorated with spiral engraving.

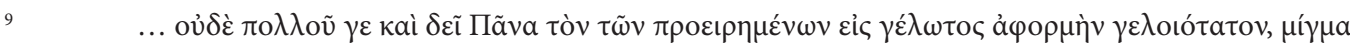

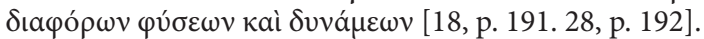

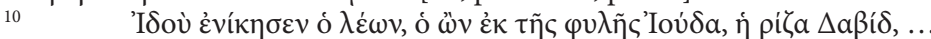

11 A heraldic lion appears on the shield of St. Demetrios on a mosaic icon (early $14^{\text {th }}$ century) of the Museo Civico, Sassoferrato [7, p. 232 no. 139] and a lion's head is depicted on the shield of St. Demetrios in the frescoes of the Perivleptos church, Mystras (1360-1380) [34, pp. 310-311]. Lion masks appear on the armours of St. George and Archangel Michael in the wall paintings (late $13^{\text {th }}$ century) of the Metropolis at Mystras [34, p. 309] as well as of St. George, St. Demetrios and Archangel Michael in the frescoes of the Perivleptos in Mystras [34, pp. 310-311].

${ }_{12}$ Cf. a nicolo intaglio $\left(2^{\text {nd }}-3^{\text {rd }}\right.$ century AD) in the Herzog-Anton-Ulrich-Museum, Braunschweig [41, p. 23 no. 51 with literature; pl. 7/51], a plasma ring stone $\left(1^{\text {st }}\right.$ century BC $-3^{\text {rd }}$ century AD) in the Metropolitan Museum of Art, New York [39, p. 85 no. 374, pl. XLVII], a red jasper ( $2^{\text {nd }}$ century AD) in the Archäologisches Institut der Georg-August-Universität, Göttingen [41, p. 88 no. 99; pl. 37/99], and a jasper $\left(2^{\text {nd }}\right.$ century AD) in the Rheinisches Landesmuseum Bonn [34, p. 99, pl. 26/95].
} 
Bonus Eventus, the Roman genius of Good Fortune ("Good Outcome"), was very frequently depicted on gems, medals and coins ${ }^{13}$. We may therefore suggest that the owner of the London ring, probably an erudite aristocrat, was aware of the male figure's identity. Although the official Byzantine view condemned nude in art [28, p. 200; 12, pp. 1500-1501; 13, pp. 97, 106-109), he nevertheless selected this pagan image for his ring's decoration, thus combining his wish for good fortune with his hope of holy protection, as expressed by the inscription.

The last ring of the group belongs to the Cabinet des Médailles of the Bibliothèque Nationale, Paris, inv. no. Luynes 36 [47, p. 36 no. 22, with literature, pl. 8]. Its flat hoop is engraved on one side, beginning with a cross, with the epigram XPICOC KOCMEI $\triangle A X T I \Lambda O N$ THN $\triangle A I$ $\Psi \Upsilon X H N \Lambda O \Gamma \Omega C$ (Gold ornaments the finger and the logos ornaments the soul). The inscription on the other side $\triangle O T E T O K \Omega C M O K E P \triangle$ is part of the epigram As soon as we gain the world, we are buried in the tomb, which paraphrases a verse from the eighth stanza of the kontakion “On Life in the Monastery" by Romanos the Melode [26, no. 55, p. 475; 45, p. 40]. Romanos' literary production was indebted to Greek patristic tradition and acquired therefore a moralizing character [29]. This epigram, encountered in three more rings of the late Byzantine period $\left[47\right.$, p. 40], as well as the whole stanza ${ }^{14}$, refers to the futility of worldly things.

The stone of the bezel is flat and engraved with a muse. She stands on a ground line, with her right foot on a podium, and holds a mask and a pedum (a shepherd's staff). Therefore she can be identified with Thalia, the muse of comedy and merry or idyllic poetry ${ }^{15}$. A $6^{\text {th }}$-century gold ring, from Syracuse, probably of local manufacture, is also set with a cornelian intaglio depicting a muse with a mask, probably Thalia [35, pp. 160-161]. An inscription incised

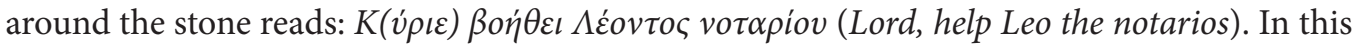
case we know that the wearer of the ring, a notarios (notary), had been a cultivated person of the Byzantine society.

If the Byzantine owner of the Paris ring had also been a cultivated person, he might have identified the depicted woman as a muse related to the theater. Sculptures, paintings and gems depicting the nine muses were numerous in Hellenistic and Roman art. The two muses - protectors of the theater are shown with a mask. Melpomene, muse of Tragedy, holds a tragic mask, while Thalia is shown with a comic one and sometimes also with a pedum. According to the didactic content of the inscriptions engraved on the ring, the gem should depict Melopomene and not Thalia. Either such a gem was not available or the gem with the image of Thalia was incorrectly selected for the Paris ring instead of a gem with a representation of Melpomene.

13 E.g.: in a jeweller's hoard from Snettisham, in Roman Britain, Bonus Eventus is depicted in the majority of the intaglios (25\%) [10, p. 296].

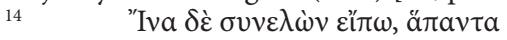

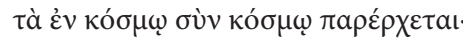

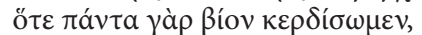

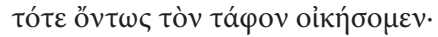

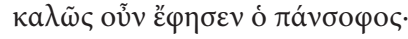

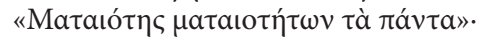

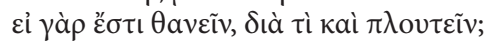

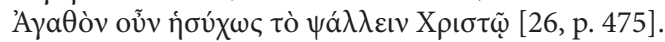

15 http://www.theoi.com/Ouranios/Mousai.html (accessed April 12, 2015). These are the attributes of Thalia in a mosaic dated to the $3^{\text {rd }}-4^{\text {th }}$ century AD in Trier (found in the Neustraße) with half-length images of the nine muses [http://www.theoi.com/Gallery/Z20.3. html (accessed April 12, 2015). 
It is generally accepted that engraved gems were not often used as seals in Byzantium [9, p. 133], therefore the five rings of our group were probably not signet rings. Their stones originate from the Roman period, when gem production was prolific. The motifs selected for their decoration were mostly mythological. Some of them, namely those of the two satyrs, the mask and the god Pan, had apotropaic connotations and of course all images of the examined ring stones have been probably considered as sources of danger, since they derived from the pagan world. Given the mediaeval prevalent belief in the stones' healing powers [31, p. 62], it can be assumed that these rings were seen as amulets - the wish for protection being far more pronounced in the Baltimore and the London rings because of their inscriptions.

Only one of our rings has an archaeological context, that from Gavalochori. The island of Crete, recaptured by the Byzantine general and future emperor Nikephoros Phokas after a long period of Arabic occupation (827-961), had strong ties to Constantinople during the middle Byzantine period. Thus, the Gavalochori ring might have been an official gift to its owner, who was perhaps a dignitary or a military officer ${ }^{16}$. Since the Thessalonike hoard, to which our second ring belonged, is a heterogeneous ensemble, consisting of Byzantine and Latin jewels, it seems likely that it was a dealer's accumulated stock or the property of a money lender [47, p. 18]. The owners of the three late Byzantine rings attributed to the court workshop were probably members of a well-educated social elite related to Constantinople. The pagan images of these ring stones were "Christianized" through the inscriptions just like the figures from the antique iconographic repertoire (personifications of melody, the night and the like), incorporated in religious miniatures of the Macedonian Renaissance - and their Palaeologan replicas - acquired a Christian content.

Although the art of gem carving was revived in Byzantium after Iconoclasm, the owners of the rings in question chose antique intaglios to decorate them. This is because they probably appreciated the art of Graeco-Roman antiquity - their own past - and believed, as also the Nicaean emperor and philosopher Theodore II Laskaris (1222-1258) did, that "the works of the dead are more beautiful than those of the living"17.

Title. Antiquity Reused. Antique Engraved Gems on Byzantine Rings.

Author. Jenny Albani - Architect, Art historian, Professor (Hellenic Open University). Directorate of Museums, Hellenic Ministry of Culture, Education and Religious Affairs. 20, Bouboulinas Str., 10682 Athens, Greece. jennyalbani@ gmail.com.

Abstract. It is nowadays generally accepted that the Byzantines were familiar with the art of the antiquity. In this context antique gemstones, cameos and intaglios, were incorporated in mediaeval jewellery, especially in rings. How did the Byzantines "reuse antiquity" in relation to their rings, these precious objects of prestige or personal adornment? Did they keep their original meaning or were they affected by Christian faith? Can we speculate on the identity of these rings' owners? These are the questions which the author of the paper tries to deal with.

Keywords: Reuse; antiquity; Roman intaglios; Byzantine rings; inscriptions; mythological motifs; piety; amulets; Western influence.

Название статьи. Возвращенная античность. Византийские перстни с античными резными камнями.

Сведения об авторе. Албани Дженни - архитектор, историк искусства, профессор (Открытый университет Греции). Дирекция музеев при Министерстве по делам культуры и религий Греции, Bouboulinas Str. 20, Aфины, Греция, 106 82. jennyalbani@gmail.com.

16 A well-known practice from the early Byzantine period onwards [45, p. 18].

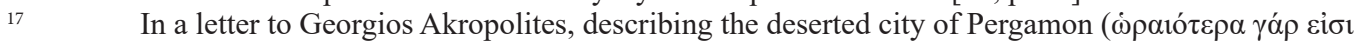

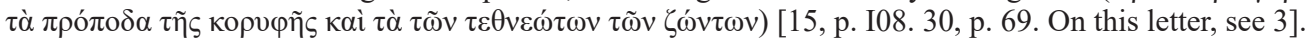


Аннотация. Сегодня общепризнано, что наследие античности было хорошо известно в Византии. Статья посвящена вторичному использованию античных резных камней - инталий и камей, в Средние века вправлявшихся в ювелирные изделия, особенно в перстни. Автор задается вопросом: как в Византии относились к перстням с античными вставками - как к знакам престижа или как к украшениям? Сохранялся ли прежний смысл этих предметов или христианство внесло в него изменения? Можем ли мы по перстню судить о личности владельца?

Ключевые слова: античность; вторичное использование; римские инталии; византийские перстни; надписи; мифологические темы; почитание; амулеты; западные влияния.

\section{References}

1. Albani J. Ei de kaka ergaze phobethete ton Kriten. Scholia se toichographia me poines amartolon ston Agio Ioanne tes Axou Mylopotamou. Studies in Honour of Manolis Borboudakis (in press).

2. Albany J. Dakhtylidia tes Vyzantines kai Metavyzantines Sylloges Khanion (Rings of Byzantine and Post-Byzantine Collection of Chania). Pepragmena tou I' Diethnous Kretologikou Synedriou Chania, 1-8 Oktobriou 2006: Byzantine kai Metabyzantine periodos (Archaiologia kai Istoria tes Technes). Chania, Philologikos Syllogos Chanion "O Chrysostomos" Publ., 2011, pp. 123-135 (in Greek).

3. Antoniadis S. Sur une lettre de Théodore II Lascaris. L’Hellénisme Contemporain, 1954, vol. VIII, no. 4-5, pp. 356-361 (in French).

4. Bosselmann-Ruickbie A. Byzantinischer Schmuck des 9. bis frühen 13. Jahrhundert. Untersuchungen zum metallenen dekorativen Körperschmuck der mittelbyzantinischen Zeit anhand datierter Funde. Wiesbaden, Reichert Verlag Publ., 2011, 207 p. (in German).

5. Bosselmann-Ruickbie A. A. $13^{\text {th }}$-Century Jewellery Hoard from Thessalonica: A Genuine Hoard or an Art Dealer's Compilation? "Intelligible Beauty". Recent Research on Byzantine Jewellery. London, The British Museum Publ., 2010, pp. 219-232.

6. Bouras Ch. Byzantines anagenneseis kai e architektonike tou 11 ou -12 ou aionos. Deltion tes Christianikes Archaiologikes Etaireias, 1969, no 5, pp. 247-98 (in Greek).

7. Brazinski P. The Little Metropolis. Religion, Politics and Spolia, Doctoral Thesis. Bucknell University Publ., 2010. 80 p. Available at http:// digitalcommons.bucknell.edu/cgi/viewcontent.cgi?article=1011\&context=honors_theses (Accessed February 22, 2015).

8. Brilliant R.; Kinney D. (eds.). Reuse value. Spolia and Appropriation in Art and Architecture from Constantine to Sherrie Levine. Surray - Burlington, Ashgate Publ., 2011, 284 p.

9. Cheynet J.-C.; Caseau B. Sealing Practices in the Byzantine Administration. Seals and Sealing Practices in the Near East. Developments in Administration and Magic from Prehistory to the Islamic Period. Proceedings from an International Workshop at the Netherlands-Flemish Institute in Cairo on December 2-3, 2009. Orienatalia Lovaniensia Analect, vol. 219. Leuven - Paris - Walpole, Uitgeverij Peeters en Departement Oosterse Studies Publ., 2012, pp. 133-148.

10. Croom A. Personal Adornment. A Companion to Roman Britain. Malden - Oxford and Victoria, Blackwell Publ., 2006, pp. 288-298.

11. Cutler A. On Byzantine Boxes. Journal of the Walters Art Gallery, 1984-85, no. 42-43, pp. 32-47.

12. Cutler A.; Kazhdan A. Nude. Oxford Lexicon of Byzantium. New York - Oxford, Oxford University Press Publ., 1991, vol., III, pp. 1500-1501.

13. Dauterman Maguire Eu.; Maguire H. Other Icons: Art and Power in Byzantine Secular Culture. Princeton, Princeton University Press, 2007. 201 p.

14. Evans H. C. (ed.) Byzantium. Faith and Power (1261-1557). Exhibition Catalogue. New York - New Haven London, the Metropolitan Museum and Yale University Press, 2004, 658 p.

15. Festa N. (ed.). Theodori Ducae Lascaris Epistulae CCXVII. Florence, Tipografia G. Carnesecchi e Figli Publ., 1898. $414 \mathrm{p}$.

16. Furtwängler A. Die antiken Gemmen. Geschichte der Steinschneidekunst im klassischen Altertum,vol 1. Leipzig Berlin, Giesecke und Devrient Publ., 1900, LXI p. (in German).

17. Furtwängler A. Die antiken Gemmen. Geschichte der Steinschneidekunst im klassischen Altertum, vol. 2. Leipzig Berlin, Giesecke and Devrient Publ., 1900, 331 p.

18. Halkin F. (ed.). Inédits byzantins d'Ochrida, Candie et Moscou. Subsidia Hagiographica, no. 38. Brussels, Société des Bollandistes Publ., 1963, 360 p.

19. Hamann-Mac Lean R. H. L. Antikenstudium in der Kunst des Mittelalters. Marburger Jahrbuch für Kunstwissenschaft, 1949-1950, no. 15, pp. 157-250.

20. Impellizzeri S. (ed.). Michele Psello Imperatori di Bizanzio (Cronografia), vol. I. Milan, Fondazione Lorenzo Valla Publ., 1984, 403 p.

21. Impelluso L. Gods and Heroes in Art. Los Angeles, The J. Paul Getty Museum Publ., 2002, 381 p.

22. Kakrides I. Th.; Roussos E. N.; Kamaretta Ai.; Skiadas A. D.; Papachatzes N. Ellenike Mythologia. Oi Theoi. Athens, Ekdotike Athenon Publ., 1986, 374 p. (in Greek). 
23. Kinney D. Ancient Gems in the Middle Ages: Riches and Ready-mades. Reuse value. Spolia and Appropriation in Art and Architecture from Constantine to Sherrie Levine. Surray - Burlington, Ashgate Publ., 2011, pp. 97-120.

24. Koder J. Imperial Propaganda in the Kontakia of Romanos the Melode. Dumbarton Oaks Papers, 2008, no. 62, pp. 275-291.

25. Liddel H. G.; Scott R. Mega lexicon tes ellenikes glosses, vol. IV. Athens, Ekd. Anestes Konstantinides Publ., 1907, 712 p. (in Greek).

26. Maas P.; Trypanis C. A. (eds.). Sancti Romani Melodi Cantica. Cantica Genuina. Oxford, Clarendon Press Publ., $1997,546 \mathrm{p}$.

27. Maguire H. The Cage of Crosses: Ancient and Medieval Sculptures on the "Little Metropolis" in Athens. Thymiama ste mneme tes Laskarinas Mpoura, Vol. I. Athens, Mouseio Mpenaki Publ., 1994, pp. 169-172.

28. Maguire H. The Profane Aesthetic in Byzantine Art and Literature. Dumbarton Oaks Papers, 1999, no. 53, pp. 189-205.

29. Maisano R. Romanos's Use of Greek Patristic Sources. Dumbarton Oaks Papers, 2008, no. 62, pp. $261-273$.

30. Mango C. Antique Statuary and the Byzantine Beholder. Dumbarton Oaks Papers, 1963, no. 17, pp. 53-75.

31. Mango C.; Mango Mundell M. Cameos in Byzantium. Cameos in Context. The Benjamin Zucker Lectures, 1990. Oxford and Houlton, Derek J. Content, Inc. in association with The Ashmolean Museum Publ., 1993, pp. 57-76.

32. Metzger C. Le monde byzantin. Cornaline et pierres précieuses. La Méditerranée, de l'Antiquité à l'Islam. Actes du colloque organizé au musée du Louvre par le Service culturel les 24 et 25 novembre 1995. Paris, La documentation Française Publ., 1995, pp. 77-92.

33. Migne J. P. (ed.). Patrologia cursus completus, Series graeca, CIX, Historiae byzantinae scriptores post Theophanem, Paris, Petit Montrouge Publ., 1863, 1184 p.

34. Mouriki D. The Mask Motif in the Wall Paintings of Mistra. Cultural Implications of a Classical Feature in Late Byzantine Painting. Deltion tes Christianikes Archaiologikes Etaireias, 1980-1981, no 10, pp. 307-338.

35. Orsi P. Oreficerie. Sicilia bizantina. San Giovanni La Punta, Brancato Editore Publ., 2000, pp. 135-166.

36. Papalexandrou A. Memory Tattered and Torn: Spolia in the Heartland of Byzantine Hellenism. Archaeologies of Memory. Oxford, Blackwell Publ., 2003, pp. 56-80.

37. Platz-Horster G. Die antiken Gemmen im Rheinischen Landesmuseum Bonn. Bonn, Rheinisches Landesmuseum Bonn Publ., 1984. 141 p. (in German).

38. Richter G. M. A. The Engraved Gems of the Greeks, Etruscans and Romans - Part II. Engraved Gems of the Romans. A Supplement to the History of Roman Art. London, Phaidon Press Publ., 1971. 307 p.

39. Richter G.M.A. The Metropolitan Museum of Art. New York. Catalogue of Engraved Gems. Greek, Etruscan and Roman. Rome, "L’Erma” di Bretschneider Publ., 1956. 143 p.

40. Saradi H. The Use of Ancient Spolia in Byzantine Monuments: The Archaeological and Literary Evidence. International Journal of Classical Tradition, 1997, no. 3/ 4, pp. 395-423.

41. Scherf V.; Gerke P.; Zazoff P. Antike Gemmen in deutschen Sammlungen. Braunschweig, Göttingen, Kassel, vol. 3. Wiesbaden, Franz Steiner Verlag Publ., 1970, 272 p., 118 pls. (in German).

42. Schörner G. Pan in Attika: Der Gott und sein Kult im klassischen Athen. Der Große Pan ist tot! Pan und das arkadische Personal. Worms, Wernersche Verlagsgesellschaft Publ., 2007, pp. 79-93 (in German).

43. Sena Chiesa G. Myth Revisited: The Reuse of Mythological Cameos and Intaglios in Late Antiquity and the Early Middle Ages. 'Gems of Heaven:' Recent Research on Engraved Gemstones in Late Antiquity c. AD 200-600. British Museum Research Publication. London, Trustees of the British Museum Publ., 2011, no. 177, pp. 2-10.

44. Spier J. Ancient gems and Finger Rings. Catalogue of the Collections. The J. Paul Getty Museum. Malibu - California, The J. Paul Getty Museum Publ., 1992. 184 p.

45. Spier J. Byzantium and the West: Jewelry in the First Millenium. London - Paris - Chicago - New York, Paul Halberton Publishing and Les Enluminures Publ., 2012. 207 p.

46. Spier J. Late Antique and Early Christian Gems. Wiesbaden, Reichert Verlag Publ., 2007. 221 p.

47. Spier J. Late Byzantine Rings, 1204-1453. Wiesbaden, Reichert Verlag Publ., 2013. 85 p.

48. Spier J. Some Unconventional Early Byzantine Rings. "Intelliglible Beauty". Recent Research on Byzantine Jewellery. British Museum Research Publication. London, The British Museum Publ., 2010, no. 178. pp. 13-19.

49. Weitzmann K. Euripides Scenes in Byzantine Art. Hesperia, 1949, vol. XVIII, no. 2, pp. 159-210.

50. Weitzmann K. Greek Mythology in Byzantine Art. Princeton, Princeton University Press, 1951. 218 p.

51. Weitzmann K. The Survival of Mythological Representations in Early Christian and Byzantine Art and Their Impact on Christian Iconography. Dumbarton Oaks Papers, 1960, no. 14, pp. 43-68.

52. Zwierlein-Diehl E. Antike Gemmen und ihr Nachleben. Berlin - New York, Walter de Gruyter Publ., 2007. 567 p. 